\title{
ENGINEERED OVEN AS AN ALTERNATIVE METHOD ON STAMP canting SOLDERING PROCESS
}

Oven Rekayasa Sebagai Metode Alternatif pada Proses Pematrian canting Cap

Robets Christianto, Suparjo, Hadi Sumarto, Farida and I Made Arya Utamaningrat

Center for Handicraft and batik, Kusumanegara st. No.7, Semaki, Umbulharjo, Yogyakarta City, Special Region of Yogyakarta 55166

\begin{tabular}{ll}
\hline Author Correspondence & Manuscript Entry : 16 Nov 2020 \\
Email $:$ imau90@gmail.com & Revisied $: 14$ June 2021 \\
& Approved $: 14$ June 2021 \\
\hline
\end{tabular}

Keywords: batik, oven, soldering, stamp canting

Kata kunci: batik, canting cap, oven, pelelehan patri

\begin{abstract}
batik is a process of attaching wax on to a fabric to block color. This process is done using a tool called canting. There are two kind of canting, writing canting and stamp canting, that is respectively use to make written batik and stamp batik. Stamp canting was made to accelerate the process of making batik fabric with the standards of batik itself. It was made using copper that is stacked in certain way and burned on a pile of charcoal to ensure the adhesive material (patri) melt. This research aims to accelerate the process of soldering stamp canting using engineered oven instead of charcoal. the oven engineered in this research uses Liquid Petroleum Gas (LPG) as the main heat source. It was made not only to accelerates the process, but also to make sure the consistency of the heat along the process of burning which will directly affecting the end product of stamp canting. The method used in this research includes: literature studies, field studies, oven engineering, making canting samples, test, and reporting. The result of this research shows the oven was able to reach the temperature to melt standardized patri on stamp canting, therefore able to be an alternative method in creating stamp canting.
\end{abstract}

\section{ABSTRAK}

batik adalah proses menempelkan lilin pada kain untuk merintang warna. Proses ini dilakukan menggunakan alat yang disebut canting. Ada dua jenis canting, canting tulis dan canting cap, yang masing-masing digunakan untuk membuat batik tulis dan batik cap. canting cap dibuat untuk mempercepat proses pembuatan kain batik sesuai dengan standar batik itu sendiri. canting cap dibuat menggunakan tembaga yang ditumpuk dengan cara tertentu dan dibakar di atas tumpukan arang untuk memastikan bahan perekat (patri) meleleh. Penelitian ini bertujuan untuk mempercepat proses pelelehan patri canting cap menggunakan oven rekayasa tanpa arang. Oven yang direkayasa dalam penelitian ini menggunakan Liquid Petroleum Gas (LPG) sebagai sumber panas utamanya. Oven ini dibuat tidak hanya untuk mempercepat proses, tetapi juga untuk memastikan konsistensi panas sepanjang proses pembakaran yang secara langsung akan mempengaruhi produk akhir canting cap. Metode yang digunakan dalam penelitian ini meliputi: studi literatur, studi lapangan, rekayasa oven, pembuatan sampel canting, percobaan, dan pelaporan. Hasil penelitian menunjukkan oven mampu mencapai temperatur yang dibutuhkan untuk melelehkan patri standar pada canting cap, maka oven dapat digunakan sebagai metode alternatif dalam pembuatan canting cap. 


\section{INTRODUCTION}

Batik is a cultural masterpiece of Indonesia. It was a traditional way to create motifs on a fabric. National Standard of Indonesia (SNI), SNI 0239-2014 stated that batik is a handicraft resulted from blocked coloring process using hot malam (batik wax) as the color blocker that is attached using canting tulis (writing canting) and or canting cap (stamp canting) to create certain meaningful motifs (BSN, 2014). SNI 0239-2014 also define stamp canting as a motif shaping tools made from cooper or wood used to paste malam.

Batik importance is more than a product. Since UNESCO declared batik as the Intangible Cultural Heritage of Humanity of Indonesia, batik became a tool of diplomacy. Zahidi (Zahidi, 2017) in his paper stated that Indonesian government promoting batik as a soft power instrument throughout Southeast Asia. This momentum has been beneficial for a lot of batik SME(s) in Indonesia. But within every chance, there is also a challenge follow behind. In this case, the challenge was to match the demand of the ever-growing market for batik.

Batik is a unique process that leads to a unique product. To produce a massive amount of batik product, many craftsmen is needed. Since batik is not something that can be done easily not many people are able to create a high-quality batik. To be able to create a decent batik, a person should have a decent amount of experience, therefore a regeneration is needed. The problem faced by batik community as of now is lack of regeneration for batik craftsmen (Oentoro, Amijaya, \& Seliari, 2019). Oentoro (Oentoro et al., 2019), in his research shows that batik craftsmen in an area of Yogyakarta are above 40 years old. It means that no young people making batik right now. This problem as of right now might only affecting the production capability of batik industries, but in a long term this could lead to an extinction of batik itself. One thing that becoming a primary concern right now is to continuously produce and preserving as our cultural heritage,. A regeneration is needed.

While it is true that regeneration is the main concern for batik to keep existed as Indonesian cultural heritage, there are other problem looming. One of those problem was the global competition to fulfill market's demand for batik. Other countries try to create a batik-motif fabric to fulfil those specific demand. The information regarding real batik is very limited to foreign countries and even to our local people. Many people knew batik only as the motif from certain region. This misconception of batik made batik compete with batik-motif fabric that is cheaper. With this in mind, a lot innovations have been made to make a process of making batik easier while still on the corridor of craftmanship. Many of those innovations were made for the canting.

There are two kind of canting, that is writing canting and stamp canting. Some innovations made for writing canting includes electric canting (Lestariningsih, Dharmastiti, \& Moyoretno, 2013; Syamsuri \& Abidin, 2016) and automatization of written canting (Ikawanty, Rifa'i, \& Patma, 2015). While for stamp canting, the innovations includes creating stamp canting from other materials such as duplex paper (Nurohmad \& Eskak, 2019), cardboard 
(Yanuarmi, Widdiyanti, \& Sundari, 2019) and wood (Hastuti, 2010). The innovations are not limited to material selection, many have tried to use more sophisticated method such as CNC milling machine (Hermawan \& Suwondo, 2014), electroplating (Setiawan et al., 2020) and even using additive manufacturing (Hamidi, Wibisono, \& Dharma, 2017). Although there are two well-known (wood and cooper) materials for making stamp canting, but most batik craftsman chose cooper as their main material. The main reason behind that selection is that cooper have better conductivity than wood, which directly affect the result of malam stamping.

Despite the superior thermal properties of cooper compared to other materials for this application, it has its own drawback. Shaping and assembling cooper into a fully functioning stamp canting is not an easy task. Making stamp batik is a long and complex process that need a certain knowledge, experience, and expertise. It could take up to one week for an expert to create one stamp canting.

Cooper is still the most favorite materials to create stamp canting, but it has one downside in its making process. The complexity of the motif is one reason for the long process time, the other one is the burning process. Those drawbacks worsen by a lack of stamp canting expert regeneration, thus push researcher to innovate in a more efficient and effective ways to create stamp canting using cooper.

In general the process of making stamp canting from cooper starts from preparation, frame making, attaching metal motifs, assembling motifs to the frame and handle, and finishing stamp canting designing the motif, identifying each size (frame size, thickness of the motif, etc.) (SKKNI, 2018). There are two separate processes between motif making and assembling it onto the frame, the former uses patri with higher melting temperature while the later uses a lower one. Those differences were made deliberately to make sure a higher success rate of making the stamp canting.

Traditional way of making canting includes soldering process using stacked charcoal (Figure 1). Those charcoal then burned until it smolders. The motif then put onto the smoldering charcoal and burned until it is done. Knowing that a stamp canting soldering is done was not an easy job, since the craftsmen usually use only their eyes to see the smokes coming up from the stamp canting. An inexperience craftsman might pull out the stamp canting too late and actually broke the whole process. The duration of the process itself, from preparing the charcoal until it finishes the product, could take up to an hour.

In this research we conducted an alternative method for soldering the stamp canting so it will take shorter time and easier to visually detect whether the process has been done or not. Using an engineered oven that using LPG as its source of heat.
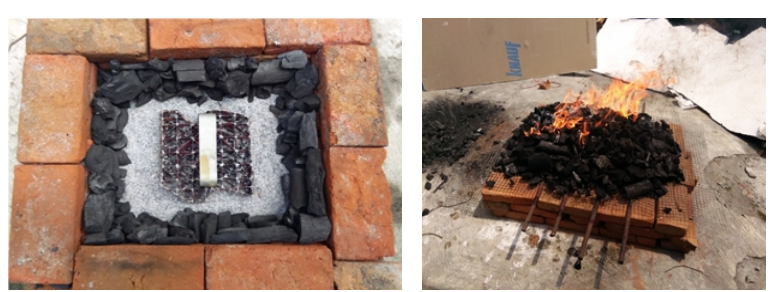

Figure 1. Conventional soldering process of stamp batik

\section{METHODOLOGY}

Materials and Tools 
a. Stamp canting making

Materials: flux, local patri, standardized patri (brazzing rod) by Harris, $0.5 \mathrm{~mm}$ thick copper plate.

Tools: little tweezer, big tweezer, copper plate cutter, bow compass, clamp, steel saw, fail, brass

b. Oven making

Materials : $0.3 \mathrm{~mm}$ thick steel plate LPG burner, refractory stones, fireproof cement, heat retarder, connector, regulator, thermocouple.

Tools : electrical welder machine set

To use the brazing rod, it was crush into pieces before we put in on the samples. The technical detail of Harris's patri shown on table 1. While the composition and technical specification of the local patri is unknown.

Table 1. Technical detail of Harris Patri (Harrisproductsgroup, n.d.)

\begin{tabular}{lll}
\hline $\begin{array}{l}\text { Chemical } \\
\text { Composition }\end{array}$ & $\begin{array}{l}\text { Solidus } \\
\text { Temperature }\end{array}$ & $\begin{array}{l}\text { Liquidus } \\
\text { Temperature }\end{array}$ \\
\hline $\mathrm{Cu}-92,75 \%$ & $1310^{\circ} \mathrm{F}$ & $1475^{\circ} \mathrm{F}$ \\
$\mathrm{P}-7,10 \%$ & $710^{\circ} \mathrm{C}$ & $802^{\circ} \mathrm{C}$ \\
$\mathrm{Ag}--\%$ & & \\
Others & & \\
$0,15 \%$ & & \\
\hline
\end{tabular}

\section{Making the Oven}

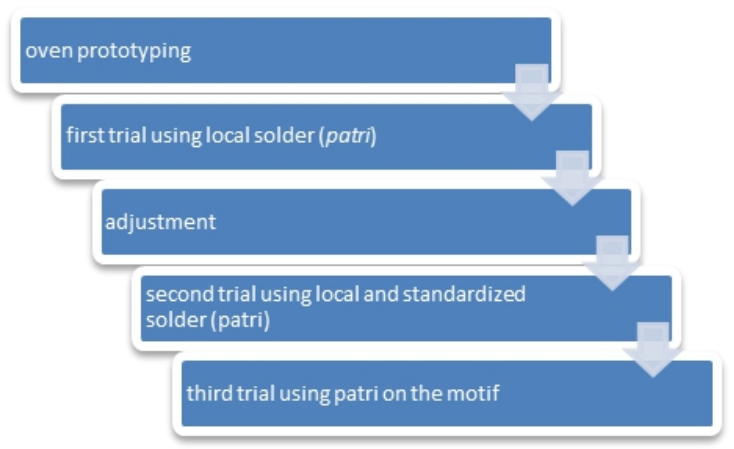

Figure 2. Flow diagram of research method

Flowchart of this research is shown on Figure 2.
Dimension are considered to be the most important thing to consider when creating this oven. Most of stamp canting has a size of $20 \times 20 \times 4 \mathrm{~cm}$. In order for the oven to be able to contain those, it has to have a chamber with a bigger dimension than $20 \times 20 \times 4 \mathrm{~cm}$.

The oven created in this research has a dimension of $40 \times 40 \times 40 \mathrm{~cm}$ with gas (LPG) as its main source of heat. Traditional method of stamp canting making uses coal as its main energy source to heat and "cook" the canting. While it is still effective, but it needs a lot of time to be burned, let alone to "cook" the stamp canting. To overcome that problem, we use gas (LPG) to heat the oven. The fire will be put directly into the chamber to heat the stamp canting inside it. Heating stamp canting inside the chamber is hoped to create a more homogenous heat all across the stamp canting.

On the first design, the burner was placed on the side of the oven, assuming that the heat will stay inside and spread evenly inside the oven. After a few tests, the burner was adjusted to the top of the oven. the fire will enter the oven chamber through this nozzle and heat the topside of the canting.

\section{Testing the Oven}

The oven was tested by using it to burn several stamp canting motifs. The motifs were treated using local patri and standardized patri from Harris. The uses of two kind of patri was intended to indicated the heat generated by the oven system.

\section{RESULTS AND DISCUSSIONS}

Oven Making 
The specification of the oven is stated on Table 2.

Table 2. Specifications of the oven

\begin{tabular}{ll}
\hline \multicolumn{1}{c}{ Specification } & \multicolumn{1}{c}{ Dimensions } \\
\hline Length $\times$ width $\mathrm{x}$ & $400 \mathrm{~mm} \times 400$ \\
height & $\mathrm{mm} \times 400 \mathrm{~mm}$ \\
Plate thickness & $3 \mathrm{~mm}$ \\
Refractory thickness & $55 \mathrm{~mm}$ \\
Exhaust & $(\mathrm{D})=29 \mathrm{~mm}$, \\
& length $=50 \mathrm{~mm}$ \\
Burner diameter & $5,2 \mathrm{~mm}$ \\
Hollow metal $(\mathrm{l} \times \mathrm{w} \times \mathrm{h})$ & $40 \mathrm{~mm} \times 60 \mathrm{~mm}$ \\
& $\times 420 \mathrm{~mm}$. \\
\hline
\end{tabular}

The oven was successfully created and able to generating heat. The physical appearance of the oven can be seen in Figure 3. The oven was created to accommodate the process of making stamp canting, especially the size of stamp canting that is considered normal that is $20 \mathrm{~cm} \times 20$ $\mathrm{cm}$.

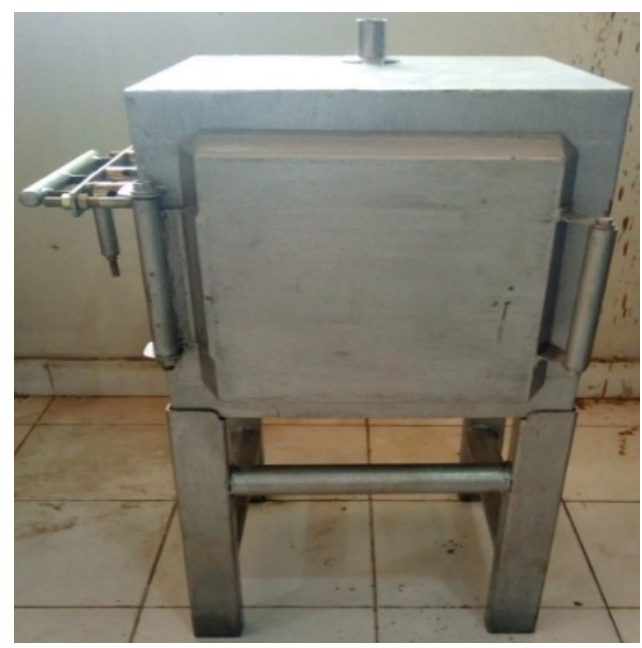

Figure 3. Oven for stamp canting

First test
First test was conducted using local patri to solder the motif. The motif with patri pasted on its joint was burned for 10 minutes, 20 minutes, and 30 minutes. After every interval, the motif was inspected visually to see whether the patri has already melted or not. After 30 minutes, as shown on Figure 3, the patri was not perfectly melted. it was balled up which was a signed of lack of heat in the oven.

\section{Second test}

At first, the burner with 3 nozzles was built on the side of the oven, but after the first tests, it was proofed to provide the oven chamber with enough heat to melt local patri. Since adding another nozzle means making this oven from the beginning, an adjustment was made to put more heat on the samples by rotating the oven and relocating the nozzles position to the top of the oven. It was analyzed that the heat generated from the burner located on the side of the oven was not enough to melt the patri on the motif, therefore the burner was relocated and the samples position inside the chamber was heighten using bricks and metal net (Figure 4). The purposed of this adjustment was to make sure that the fire axis hit directly onto the samples.

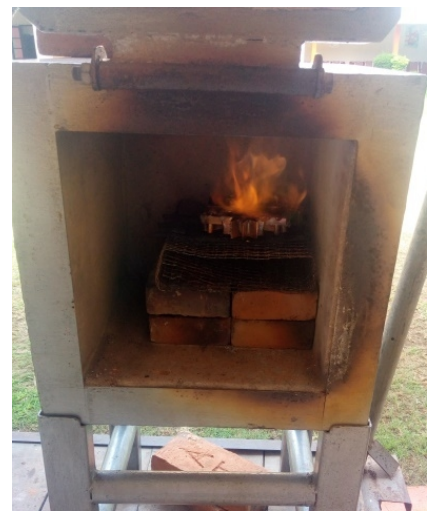

Figure 4. The oven after adjustment 
The samples were analyzed to assess the effectivity of the adjustment. From Figure 4, it can be seen that the patri from both samples were not completely melted. a granule-like shape was visibly seen on almost every joint on both samples. That visual appearance is a result of a lack of heat inside the oven which creating an imperfect soldering. Since the oven was not created with built in thermometer, there is no way to pin point the process temperature inside the oven. to analyzed the oven even further, a Harris patri was used in the process (Figure 5). a)

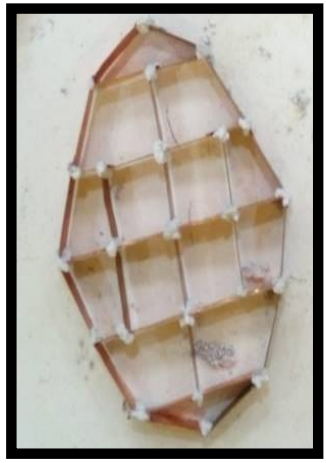

c)

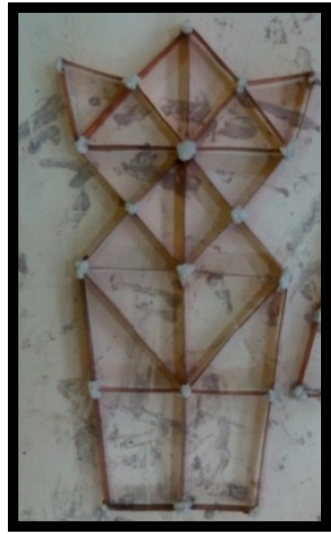

b)

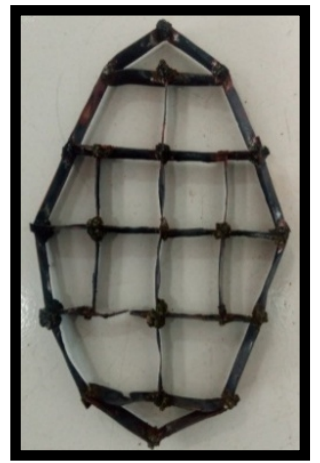

d)

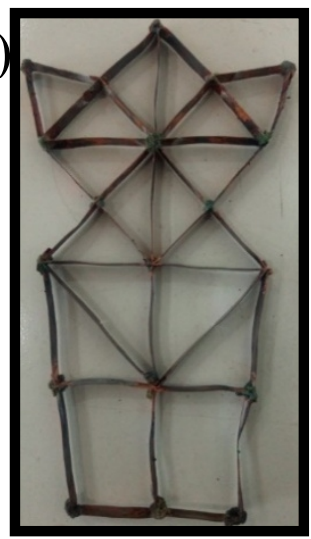

Figure 5. a) sample motif a before process; b) sample motif a after process; c) sample motif $b$ before process; $d$ ) sample motif $b$ after process

After the first test that resulted in a failure of the patri to melt, another test was conducted using standardized patri from Harris (US 2005/0249629 A1, 2005). The test was design to create some distinct visual differences between two kinds of patri, one from Harris that is standardized and the other from local store. A mesh of copper was made and given two different patri on each side. That sample was then burned and inspected every 10 minutes. The result of said process shown on Figure 6 .

After 20 minutes, the samples already shown a distinct visual appearance in which the left side of the sample (with Harris patri) was visibly better than its right side. From this conclusion, two statements were made: Local patri have a higher melting temperature than $802^{\circ} \mathrm{C}$ and the adjustment was able to create stamp canting using standardized patri from Harris. Based on that statement, we conduct the third test/patrion motif test.

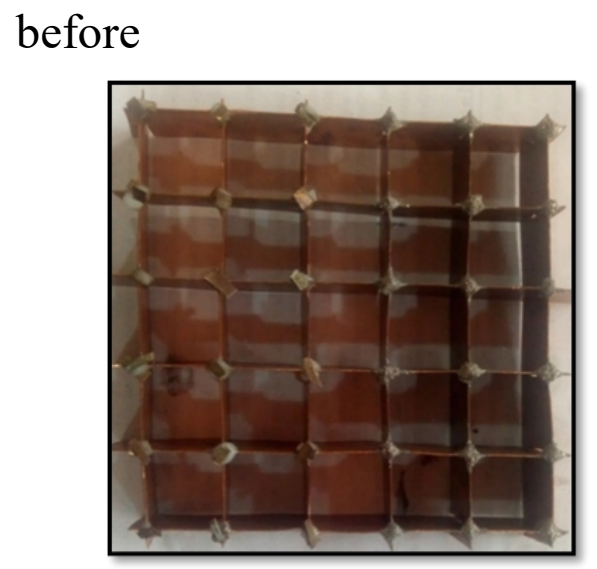

after

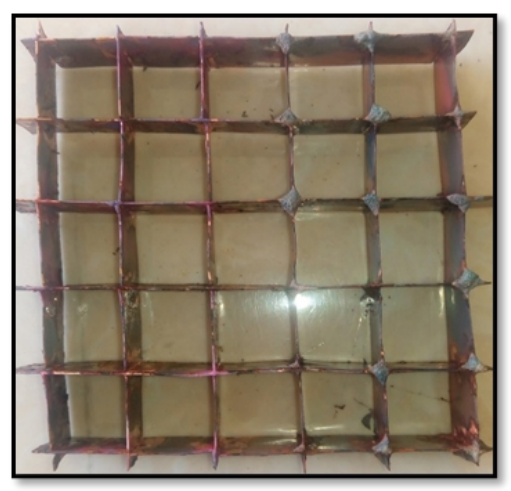

Figure 6. Second test (using 2 (two) different kind of patri. Harris patrion the left side and local patri on the right side) 


\section{Third Test/Patri on Motif Testing}

The third test was conducted to know the ability of the engineered oven capability to melt patri on motif joint and the time needed to do it. Based on the result of second test, Harris's patri was used to complete the soldering process of making stamp canting motif $(11 \mathrm{~cm} \times 11 \mathrm{~cm})$ and handle. The heating process conducted for 10 minute that is, based on the result of the second test, concluded as the optimum duration of heating for soldering using Harris's patri. The 10 minutes duration for soldering process in stamp canting making

is a significant improvement. On the conventional method of soldering, it will take around 20 minutes just to melt the patri (Sangaji, 2017). With this oven, the preparation time needed to do soldering process, such as stacking the charcoal and metal net, could be skipped. The visual appearance of the third test can be seen on Figure 7.

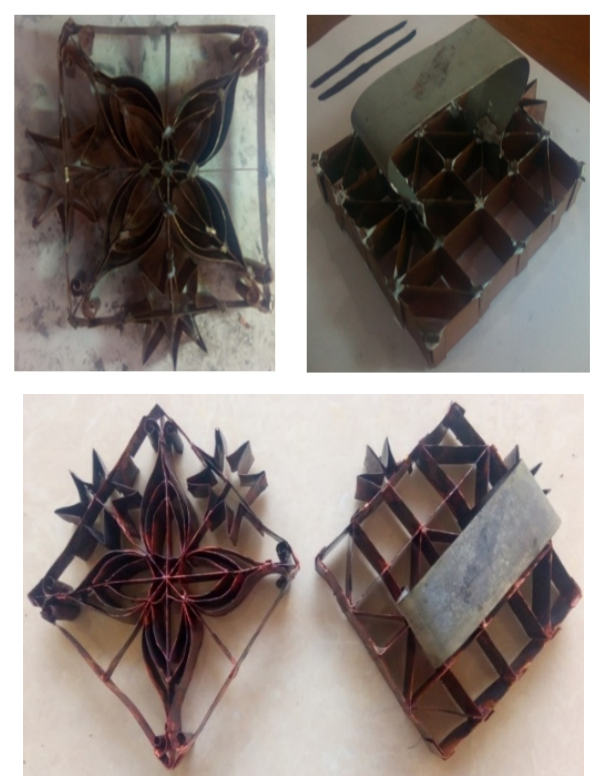

Figure 7. Third test using Harris's patri (upper picture set shown the motif and handle before soldering process; bottom picture shown the motif and handle after soldering process)
The motif and handle in the third test were put into the oven for about 10 minutes. After 10 minutes, the samples were then taken out of the oven and being observed visually. The result was the patri succeeded to melt perfectly into the joint of the samples. The oven was able to made a motif and handles of stamp batik. however, to create a whole and fully functional stamp canting, a different kind of patri with lower melting temperature was needed. Since such patri is not something that is normal in the market, therefore further research about low-melting temperature patri should be conducted.

\section{CONCLUSION AND SUGGESTIONS}

\section{Conclusion}

The oven was able to finish the soldering process for stamp batik. Using Harris's patri, 10 minutes was needed to create a motif and handle joint glued together. It was a significant improvement from a traditional way soldering process for stamp canting where it could take up to 1 hour from start to finish. The heat consistency making it possible for the patri to be perfectly melted all across the motif.

\section{Suggestions}

Further research about low-melting temperature patri should be conducted. Some improvement for the oven should be made, especially adding a thermometer and the amount of burner for the oven.

\section{AUTHOR CONTRIBUTION}

Every writer on this paper is a primary contributor. 


\section{ACKNOWLEDGEMENT}

Our deepest gratitude for Ministry of Industry of Republic of Indonesia, especially for Center for Craft and batik as our stakeholder. We would like to say thank you for everyone who helped us with this research and making it into a published academic paper.

\section{REFERENCES}

BSN. (2014). SNI 0239:2014, batik - Pengertian dan Istilah, 1-7.

Hamidi, K., Wibisono, M. A., \& Dharma, I. G. B. B. (2017). Pengembangan canting Cap Berbahan Plastik Menggunakan Teknologi Additive Manufacturing. Prosiding Seminar Nasioanl Teknik Industri Universitas Gadjah Mada 2017, (November), 66-75.

Harris, J. W. (2005). US 2005/0249629 A1. United States.

Harrisproductsgroup. (n.d.). Harris Brazing Alloy. Retrieved November 13, 2020, from https://www.harrisproductsgroup.com/en/ Products/Alloys/Brazing/PhosCopper/Harris-0.aspx

Hastuti, L. S. S. (Balai B. K. dan B. (2010). Tinjauan Tekno Ekonomi Cap batik Dari Bahan Kayu. Dinamika Kerajinan Dan batik, 27(1), 9-20.

Hermawan, I., \& Suwondo, A. (2014). Bahan Alternatif Pembuatan canting batik Cap (Cbc), 25-31.

Ikawanty, B. A., Rifa'i, M., \& Patma, T. S. (2015). Otomatisasi canting Listrik untuk Pembuatan batik Tulis Probolinggo [Electric canting Otomation for Hand Drawn batik of Probolinggo]. Prosiding SENTIA 2015 - Politeknik Negeri Malang, 7. Lestariningsih, S., Dharmastiti, R., \& Moyoretno, B. (2013). Evaluation of Electrical canting (Cantrik lama) as the Basis for Improvement Electrical canting (Cantrik) Development. Dinamika Kerajinan Dan batik: Majalah Ilmiah, 30(1), 53-66. https://doi.org/10.22322/dkb.v30i1.952

Nurohmad, \& Eskak, E. (2019). Limbah Kertas Duplex untuk Bahan canting Cap batik. Dinamika Kerajinan Dan batik: Majalah Ilmiah, 36(1), 81-94.
https://doi.org/10.22322/dkb.V36i1.41 49

Oentoro, K., Amijaya, S. Y., \& Seliari, T. (2019). Analisis Pengembangan Wirausaha batik Tradisional, 3(1), 1-7.

Sangaji, B. (2017). Life Cycle Impact Assessment Produk canting Cap batik.

Setiawan, J., Eskani, N., Besar, B., Yogyakarta, B., Kusumanegara, J., \& Yogyakarta, N. (2020). Proses Electroforming Tembaga pada Bahan Acrylic untuk Prototype canting Cap batik, (2014), 14-15.

SKKNI. Penetapan Standar Kompetensi Kerja nasional Indonesia Kategori Industri Pengolahan Golongan Pokok Industri Tekstil Bidang Industri Kain batik (2018). Kementerian Perindustrian.

Syamsuri, H., \& Abidin, Z. (2016). Re-desain canting listrik untuk meningkatkan produktivitas pengrajin batik ciamisan. Jurnal Media Teknologi, 03(01), 71-83.

Yanuarmi, D., Widdiyanti, W., \& Sundari, S. (2019). Kreatifitas Melalui batik Cap Dari Karton Bekas Pada Siswa Disabilitas. Batoboh, 4(2), 69. https://doi.org/10.26887/bt.v4i2.899

Zahidi, M. S. (2017). batik as Indonesian public diplomacy in Asean economic. International Journal of International Relations, Media and Mass Communication Studies, 3(2), 1-9. 